\title{
Tenured Women at Berkeley Before 1980
}

Cathy Kessel

One way to measure the progress of women in mathematics is to look at their presence or absence at elite institutions. Table 1 lists mathematics departments that are often considered the "top ten," the first woman tenured in each department before 1980, and the year when the department granted its first $\mathrm{PhD}$ to a woman. Of the institutions listed in Table 1, UC Berkeley (UCB) is unique in having had more than one tenured woman in its mathematics department before $1980 .^{1}$

In this article, I recount the history of those women and some notable contemporaries, illustrating how attitudes about women affected their participation in mathematics with regard to education, research, and especially employment. Attitudes about women were (and are) instantiated in a variety of ways, including customs, policies, and individual actions. In this article, examples of each appear in the national events and local actions associated with changes for women in academia, in mathematics, and at Berkeley.

Cathy Kessel is a consultant who lives in Berkeley, CA. Her email address is cbkesse1@earth1ink. net.

A version of this article with more detailed references is posted on the author's website, https://works.bepress.com/cathy_kesse1.

${ }^{1}$ Here, I use "tenured" to refer to full and associate professors. At Berkeley, the common understanding was that full and associate professors were tenured. However, tenure was not included in Berkeley's regulations until 1958 [14]. I use "tenure-track" or "professorial rank" to refer to professorial positions that are tenured or tenure-eligible and distinguish them from positions such as research associate, lecturer, and instructor.

Communicated by Notices Associate Editor Laura Turner.

For permission to reprint this article, please contact: reprint-permission aams.org.

DOI: https://dx.doi.org/10.1090/noti 2448

\begin{tabular}{lll}
\hline institution & $\begin{array}{l}\text { first tenured woman } \\
\text { before 1980 }\end{array}$ & $\begin{array}{l}\text { first woman } \\
\text { PhD }\end{array}$ \\
\hline Chicago & 1930 Mayme Logsdon & $\begin{array}{l}1908 \\
\text { UC Berkeley }\end{array}$ \\
1931 Pauline Sperry & $\begin{array}{l}1911 \\
\text { Stanford }\end{array}$ & 1969 Mary Sunseri \\
Caltech & 1971 Olga Taussky Todd & 1964 \\
MIT & 1978 Michèle Vergne & 1930 \\
Columbia & - & 1886 \\
Harvard & - & $1917^{*}$ \\
Michigan & - & 1914 \\
Princeton & - & 1972 \\
Yale & - & 1895 \\
\hline
\end{tabular}

* Radcliffe College

Table 1. Women in mathematics departments. Dates of first PhDs and MIT entry from [16]. Other sources posted at https://works.bepress.com/cathy_kesse1.

Table 2 shows how the composition of the UCB tenure-track faculty changed over the decades.

\begin{tabular}{lccc}
\hline academic year & total & women & percent women \\
\hline $1928-29$ & 15 & 2 & 20 \\
$1938-39$ & 19 & 2 & 11 \\
$1948-49$ & 27 & 2 & 7 \\
$1958-59$ & 38 & 1 & 3 \\
$1968-69$ & 81 & 0 & 0 \\
$1972-73$ & 68 & 0 & 0 \\
$1982-83$ & 69 & 3 & 4 \\
$1991-92$ & 62 & 2 & 3 \\
Spring 2020 & 57.5 & $10.5^{*}$ & 18 \\
\hline
\end{tabular}

*One appointment is half time in physics. One is a teaching professor.

Table 2. Tenure-track faculty in UCB mathematics department. 


\section{HISTORY}

\section{Overview and Major Historical Sources}

In her three volumes on women scientists in America from early times to the present, Margaret Rossiter has created extraordinarily detailed and readable narratives that synthesize a vast amount of complex information, helping us to see the context in which the people represented in Tables 1 and 2 lived.

In the early 1900s, a large percentage of women mathematicians were employed at women's colleges but were expected to resign after marriage [17]. Those who were already married were not given equal opportunity for employment [17]. Similar phenomena were the "marriage bars" that arose in the late 1800s, expanded during the Depression, and lasted until the 1950s. These were policies of firing women who married and not hiring women who were already married. Primarily affected were white US-born women, who predominated in occupations such as teaching and clerical work, rather than Black and foreign-born women in occupations such as manufacturing, waitressing, and domestic service.

In the 1920s, universities began to establish anti-nepotism rules in order to avoid being a "dumping ground" for patronage appointees from state governments. These were applied primarily to restrict rather than prohibit the employment of married women when their husbands were on the faculty, thus they were, in a sense, less restrictive than marriage bars. Anti-nepotism rules generally allowed a married woman to hold a faculty position elsewhere (such a position might be found at women's colleges which had begun to show a "modest tolerance" toward retaining women who married) or hired as a research associate at the same university as her husband [17]. The practice of tenure began in the 1930s and was adopted by the American Association of University Professors in 1941, along with the recommendation that no full-time faculty member be kept untenured for more than seven years. At coeducational institutions, this combination of tenure practices and anti-nepotism rules tended to work to the advantage of men, helping to preserve them from female competition during and after the Depression [17]. In the case of married couples, implementation of anti-nepotism rules tended to result in tenure-track positions for husbands and non-tenure-track position for wives [18], even sometimes depriving wives of tenure. ${ }^{2}$ Among the rare exceptions was the astronomer Cecilia Payne-Gaposchkin. In 1956, she became one of the first female full professors at Harvard. Her husband was a research astronomer at the Harvard College Observatory [18].

\footnotetext{
${ }^{2}$ An example from the 1950s: Josephine Mitchell and Lowell Schoenfeld were both professors in mathematics at the University of Illinois. She had tenure, he did not. After they married, she was informed that she would not be reappointed [18, see also 15].
}

Of the 228 American women who earned mathematics doctorates before 1940, 40\% were married to men with PhDs in mathematics and 21\% to men with PhDs in other fields. We know this, and much more, from the work of Judy Green and Jeanne LaDuke $[9,10]$. In the supplementary material for their remarkable book Pioneering Women in American Mathematics: The Pre-1940 PhD's, Green and LaDuke have collected and updated material on each of these women, collecting information on all doctorate-earners of that period who were born in the US or who earned their doctorates from a US institution. ${ }^{3}$ PhDs from the next 20 years are the subject of Margaret Murray's Women Becoming Mathematicians: Creating a Professional Identity in Post-World War II America.

The rise, fall, and rise of the percentages in Table 2 is part of a larger pattern for women in mathematics (see Figure 1), which, as Murray points out, reflects social, political, and economic trends, first the Depression, then the onset of World War II. She notes that the decline in women's share of PhDs occurred during the period from 1945 to 1955, "just as mathematics entered a period of unforeseen power, prestige, and prosperity" in the United States [15]. Although the number of PhDs granted to women increased, they were part of a much larger total due to the post-war influx of graduate student men in the sciences. In Table 2, this period of mathematical prosperity is reflected in the post-1950s increases in its first column (the total number of tenure-track faculty in the UCB mathematics department).

Details about these increases are given in Mathematics at Berkeley: A History written by Calvin Moore, a long-time UCB faculty member and former dean and department chair. In particular, its increases in faculty members coincide with its increased focus on research and the appointment of Griffith Evans as chair in 1936. Under Evans, who served as chair until 1949, the department became one of

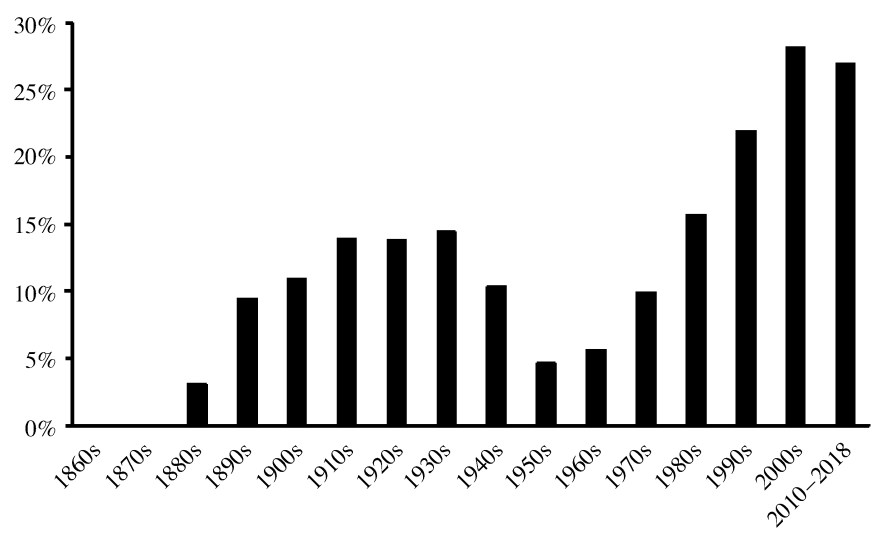

Figure 1. Percentage of US mathematics PhDs awarded to women by decade. Sources: [15] (1862-1994); Survey of Earned Doctorates (1995-2019).

\footnotetext{
${ }^{3}$ They include, for example, US-born Mary Winston Newson (PhD Göttingen 1897) and Chinese-born Shu Ting Hsia (PhD Michigan 1930).
} 
the top ten departments in the United States, and its ranking moved further upward thereafter [14].

Another view of the department comes from the work and biography of statistician Elizabeth Scott, who was a UCB faculty member from 1950 to 1988. She served on campus and national committees on women, and published research on a wide range of topics, including equity in academia.

Additional information comes from other Berkeley graduates and faculty members. Among other things, these accounts sometimes give the rationales and reasoning put in writing when hiring (or not hiring) female mathematicians, detailing local responses to policies such as anti-nepotism or affirmative action. In the 1970s, many of these accounts appeared in the Newsletter of the Association for Women in Mathematics [1].

\section{1: The First Female PhD at Berkeley}

Before 1890, most PhD programs in the United States did not allow women to enroll, although they could sometimes participate by making special arrangements [17]. Even when women could enroll, finding a PhD advisor may have been an obstacle. Anecdotes ${ }^{4}$ and records of advisees (see Appendix) suggest that faculty members were sometimes unwilling to advise students from particular demographic groups or unsuccessful in doing so. The first $\mathrm{PhD}$ in mathematics from a US university awarded to a woman went to Winifred Edgerton in 1886. The first African American man known to have been awarded a US mathematics doctorate was Elbert Frank Cox, who earned his in 1925. The first African American woman, Euphemia Lofton Haynes, earned her doctorate in 1943, almost two decades later. Of the 228 women in Green and LaDuke's study, only one (Shu Ting Hsia, PhD 1930) seems to be of Asian heritage and none are said to be Latina or Indigenous.

In 1911, Annie Dale Biddle became the first woman and third person to earn a $\mathrm{PhD}$ from the Berkeley mathematics department [10]. She was the first of seven women who earned PhDs at Berkeley before 1940.

After receiving her $\mathrm{PhD}$, Biddle taught mathematics for a year as an instructor at the University of Washington in Seattle. She returned to Berkeley; married in 1912; and taught as a teaching fellow (1914-16), assistant in mathematics (1916-17), associate in mathematics (1920-23), and instructor (1924-33). In 1933, she was one of four instructors considered for non-reappointment because the department had decided to concentrate more on its graduate program [10]. Thus, the impetus that led to hiring Griffith Evans to build up the department also led to Biddle's termination.

\footnotetext{
${ }^{4}$ For example, in the 1960 s Vivienne Malone Mayes was admitted to graduate school but could not enroll in one professor's course. "He didn't teach Blacks. And he believed the education of women was a waste of the taxpayer's money" [6].
}

Her file noted that she would not be destitute because she had married a practicing attorney. In contrast, the three male instructors were retained, one because he had a wife and children to support [14].

Biddle was far from being the only woman with a PhD who held a variety of non-tenure-track positions. And Berkeley was far from being the only university that employed female doctorates in such positions [9, 17].

\section{3 and 1924: The First Two Female Professors}

In 1923, Pauline Sperry became the first woman to attain a tenure-track position in mathematics at the University of California, six years after she had been hired as an instructor. She was one of the few women with a mathematics doctorate earned before 1940 whose primary employment was a professorial position at a PhD-granting institution $[9,10]$

Sperry was joined by female colleagues, Sophia Levy in 1921, and Emma Lehmer in 1940.

Unlike Sperry, who earned a PhD in mathematics from the University of Chicago, Levy's doctorate was from the UCB astronomy department and her undergraduate degree was also from UCB. In 1921, she joined the mathematics department as an instructor, advanced to assistant professor in $1924,{ }^{5}$ and became a full professor in 1949. Along with Annie Biddle and the three other instructors, she and a male assistant professor were considered for termination in 1933. In the end, both assistant professors were retained in order to allow Evans to make the decision about their termination. At that time, her file noted that she was the sole support of her ailing mother [14]. After his retirement, she married John Hector McDonald, thus avoiding the effects of Berkeley's anti-nepotism rule.

The anti-nepotism rule shaped Emma Lehmer's life in a different way. After her father-in-law Derrick Norman Lehmer retired in 1937, Emma's husband Dick was able to join the UCB mathematics department as one of the tenure-track faculty. However, Emma Lehmer never had a tenure-track position, thus does not raise the count in Table 2. Here we see a different accommodation to anti-nepotism rules. Dick Lehmer held several research appointments, then a faculty position at Lehigh University until his father retired. Emma Lehmer, on the other hand, did not hold a professorial position. In his account of the UCB department, Calvin Moore explains that because Lehmer's husband held a faculty appointment, "the university's nepotism regulations did not permit her to hold a faculty position except for some short-term visiting positions to meet teaching needs."

Those "teaching needs" occurred during World War II (see the online exhibit "The Lehmers at Berkeley"). During this period, male faculty members often left for government

\footnotetext{
${ }^{5} \mathrm{An}$ in memoriam article gives different dates: 1923 and 1925.
} 
science projects or military service and universities sometimes rescinded their anti-nepotism rules, reinstating them after the war was over [18].

In contrast to Levy and Lehmer, Pauline Sperry did not marry. For many years, she shared a residence in Berkeley with her close friend Alice Tabor, who was a member of the German department and, like Sperry, had a PhD from the University of Chicago. Sperry and Tabor initiated Berkeley's Faculty Women's Club in 1919 [10].

Education and scholarly activities: A comparison. Sperry (1885-1967), Levy (1888-1963), and Lehmer (19062007) came to Berkeley at different times, with different credentials, and different past experiences.

Sperry came from the East Coast. She attended Olivet College and later Smith College, then earned a PhD from the University of Chicago in 1916 with a thesis in projective differential geometry. After a year as an assistant professor at Smith, she joined the UCB faculty as an instructor, eventually rising to the rank of associate professor. At Berkeley, she taught graduate courses in differential geometry and supervised five PhD students-more than any pre-1940 woman US PhD except Anna Pell Wheeler. During World War II, she taught a course on navigation. She published an article based on her dissertation, gave talks at AMS meetings, and wrote textbooks on spherical and plane geometry. She served as vice-chair, then chair of the Northern California section of the MAA [10].

Levy was born in Alameda, California-a few miles from the university. There, she majored in astronomy as an undergraduate and wrote her dissertation in astronomy. She contributed to a National Academy of Sciences publication and wrote numerous items in the Lick Observatory Bulletin. She was deeply engaged in secondary teacher preparation, serving on regional and state committees on mathematics education. During World War II, she taught courses and wrote a textbook on the mathematics of antiaircraft gunnery. She cofounded the Northern California section of the MAA and served as its secretary, vice-president, president, and sectional governor [14].

Lehmer was born Emma Trotskaya in Samara, Russia and came to Berkeley (and the US) for college in 1924. There she assisted Derrick Lehmer on a number theory project and met his math major son Dick. After Emma finished her bachelors degree in mathematics and Dick returned to Berkeley from a year of graduate school at the University of Chicago, they married. They went to Brown University where Emma enrolled in the masters program and Dick in the doctoral program. ${ }^{6}$ After they completed their degrees

\footnotetext{
${ }^{6}$ Some speculations: Financial considerations may have played a role in Emma's decision not to get a PhD. Gertrude Stith, the other woman enrolled in the graduate mathematics program at Brown at that time, could not complete her degree there for financial reasons and went to the University of Illinois where she had obtained an assistantship [10]. Lehmer may also have been aware that her employment prospects were limited not only by anti-nepotism rules but also by being Jewish.
}

in 1930, they traveled for Dick's employment to various locations (California Institute of Technology, Stanford University, Institute for Advanced Study, Cambridge University, Lehigh University), and returned to Berkeley in 1940 [14]. Emma was an active researcher, an author or co-author of 56 papers, and a Russian translator for the American Mathematical Society. In 1968, she and her husband founded the West Coast Number Theory meeting - "a comfortable, friendly, and informal environment where [young people] can find their way into the real world of mathematics" [5].

Each of these women led an active intellectual life, but Emma Lehmer's circumstances, which included a mathematician spouse who was in the same field and opportunities for travel and interaction with other researchers, seem to have helped her to become part of a mathematical research community in a way that Pauline Sperry and Sophia Levy did not. For example, she said of the year that she and her husband spent at the Institute for Advanced Study.

I had a one-year-old girl. It was a rare occasion when I could get a babysitter and come to somebody's lecture. I did manage a few, but not very many that year. We had people come to the house, and we saw a lot of [number theorist $\mathrm{H}$. S.] Vandiver. He did not have anybody else in number theory to talk to really. He was a constant visitor. I got quite a lot of inspiration and wrote a paper as a consequence of my talking to him.

The Lehmers' reputation for hospitality at Berkeley and their founding of the West Coast Number Theory meeting suggests that Emma Lehmer's interaction with Vandiver was far from being an isolated incident in her life.

The highest academic ranks awarded to Lehmer, Sperry, and Levy were, respectively, occasional lecturer, associate professor, and professor. This ordering corresponds to their degree of involvement in activities related to undergraduate education: textbooks for service courses, MAA governance, and, in Levy's case, teacher education.

This correspondence may not be a coincidence. Within US mathematics, research and teaching had begun to separate in the 1920s, and this rift intensified over the decades. It had a gendered aspect: research and the AMS were associated with men. Women were more welcome as officers and as contributors in the MAA, whose purview included teaching, history, and scholarship [15].

Attitudes about women's academic employment. During the period when Sperry, Levy, and Lehmer were educated, few women mathematicians and scientists were faculty members at major universities. Of those few, only a small percentage advanced beyond the rank of associate professor $[9,17]$. Senior women scientists advised their juniors to get satisfaction from work, not advancement. Some claimed-"publicly at least," as Rossiter notes-to have 
been quite happy with their treatment and unaware of differences in status. ${ }^{7}$

Sperry, Levy, and Lehmer seem to have behaved similarly. Lehmer's unpublished essay "On the Advantages of Not Having a PhD" says the first advantage is "lower expectations. If one happens to discover something new, one's peers are surprised and generous in their praise." A short biography of Lehmer based on a 1996 interview concludes, "Not being a particularly competitive person, Emma did not miss the prestige of holding a faculty position."

When interviewed in the 1980s, members of the Berkeley Women's Faculty Club did not describe Sperry, Levy, or other faculty women of their era as expressing frustration about academic rank. "I think they felt embattled. ... but [I] did not ask if they felt hurt or demeaned" said an English professor colleague, although she did say that Sperry "would barge up and down the hall, saying 'Damn Professor So-and-So!'”

Rossiter remarks that for women professors at major universities, such as Sperry and Levy, promotions were gifts from colleagues, not necessary consequences of good work [17]. It was better not to think about discrimination and avoid being labeled as an ingrate or troublemaker. Promotion could draw resistance and criticism from colleagues and others. An extreme case from 1936 (described in more detail later in this article) was the German physicist Hertha Sponer's appointment as full professor at Duke University which elicited a letter from a physicist on the opposite coast.

Even if an entire mathematics department supported an appointment, it might fail. For example, at University of Michigan in the 1930s, the appointment of William Claytor, the third Black person to earn a PhD in mathematics, was fully supported by the department. However, as faculty member Raymond Wilder put it, "the administration was simply afraid," and the appointment was not made. In the 1940s, the appointment of Black statistician David Blackwell at Berkeley was stymied by the department chair's wife who said that she would not accept him at social functions. ${ }^{8}$

\section{0-1953: Then There Were Three}

Due to her refusal to take the newly established "loyalty oath" requiring employees to swear that they were not members of the Communist Party, Pauline Sperry left the

\footnotetext{
${ }^{7}$ Similar themes occur in Cathleen Morawetz's account of a conversation with Olga Taussky Todd around 1968, "[I]t was an opportunity for her to put away her wonderful smile and air her complaints. Her greatest difficulties had come from being both Jewish and a woman. Her early year in Bryn Mawr had been difficult, and not having a regular position at Caltech rankled within her. But her beloved work in mathematics saved her" [6].

${ }^{8}$ In 1954, after he established an independent UCB statistics department, Jerzy Neyman hired Blackwell who became the first Black tenured UCB faculty member. In 1965, Blackwell became the first Black member of the National Academy of Sciences.
}

mathematics department in 1950 [7]. Despite her departure, in 1951 three of the remaining 26 tenure-track faculty members were female: Sophia Levy, and the two assistant professors Elizabeth Scott and Evelyn Fix [7].

Like Sophia Levy, Scott had been an undergraduate at UCB and her doctorate was from its astronomy department. Her official advisor was Robert Trumpler, an astronomer, although her biographer Golbeck says, "it was clear" that Jerzy Neyman, a statistician, acted as a co-advisor. Between 1939 (when she received her bachelor's degree) and 1949 (when she received her doctorate), she held a variety of appointments, including that of research assistant in Neyman's statistics lab.

Evelyn Fix earned her bachelor's and master's degrees in mathematics at the University of Minnesota, before working as a high school mathematics teacher, secretary, and school librarian in Seattle from 1934 to 1941. During that time, she attended UCB summer courses. She then moved to Berkeley to work in Neyman's statistics lab and received her doctorate (with Neyman as her advisor) in 1948.

Neither Scott nor Fix married, thus avoiding direct consequences of the anti-nepotism rule. Fix shared a house with F. N. David, who had been a student of Neyman's in London and was, among other accomplishments, the founding chair of the UC Riverside statistics department. All three women were well regarded as statisticians and became fellows of the Institute of Mathematical Statistics, David in 1946, and Fix and Scott in 1951 while they were still assistant professors.

\section{4-1959: And Then There Was One}

In 1954, Sophia Levy retired, ending the mathematics department's involvement with K-12 education [14]. In the following year, Elizabeth Scott moved to the newly established statistics department, serving as its chair from 1968 to 1973 [7]. The entry for 1958 shown in Table 2 suggests that Evelyn Fix remained in the mathematics department until academic year 1958-59. Her obituary indicates that she became a professor of statistics in 1963.

\section{Zero}

After one hundred years of its existence, four women had been professors in the Berkeley mathematics department. Of these, only the first (Pauline Sperry) had earned her doctorate at an institution other than Berkeley. Levy's and Scott's PhDs were in astronomy and Fix's in statistics, although granted by the mathematics department.

As indicated in Table 3, Scott left the mathematics department in 1955 and became a member of the newly created statistics department. Table 3 would have been considerably shorter had the statistics department been established earlier, as Neyman had wished [14]. 


\begin{tabular}{ll} 
year & names of female professors \\
\hline 1923 & Sperry \\
1924 & Sperry, Levy \\
1951 & Levy, Scott, Fix \\
1954 & Scott, Fix \\
1955 & Fix \\
1963 & Fix promoted to professor of statistics
\end{tabular}

Table 3. Female tenure-track faculty in UCB mathematics department.

The mathematics department felt Scott's influence in various ways. For example, the construction of Evans Hall, a building named in honor of Griffith Evans and designed to house the mathematics and statistics departments, began in 1968. Scott ensured that every floor had toilet facilities for women, not without struggle [7]. A less concrete influence was her work on equity.

In 1969, the faculty Committee on Policy observed that, among other things, "it is surprising that so few womenonly 15 at the present time-achieve the rank of full professor at Berkeley." (Statistics for leading universities show this was not surprising at all $[18,19]$.)

At Berkeley, a Subcommittee on the Status of Academic Women (CSAW) was appointed, cochaired by Elizabeth Scott. The subcommittee's report, produced a year later, displayed the pre-1970 statistics shown in Table 2 and stated that,

45 women are appointed to ladder [tenure-track] positions which carry Senate membership and that the proportion of women in the Senate is less than it has been at any time since the 1920s. This fact alone warrants quick action to ensure that conditions leading to such a situation be rectified.

The report recommended rescinding the anti-nepotism rule, establishing paid maternity leave, and "an ultimate goal of having a representation of qualified women faculty at each rank at least in rough proportion to the number of women trained in that field." For mathematics, this "ultimate goal" would have been at least 5\% (see Figure 1).

The Berkeley CSAW report was one tributary in the flood of reports on the status of academic women that appeared across the United States in the spring of 1970, "just in time to be reprinted in congressional hearings on discrimination on campuses" which became the basis of Title IX [18].

\section{0: Affirmative Action}

Between the appointment of the Berkeley CSAW and the completion of its report, a landmark event occurred. Bernice Sandler, a psychologist who had raised two children while teaching part-time at the University of Maryland, had completed her doctorate in clinical psychology and applied for full-time positions there in 1969. She was rejected for these and other positions for reasons such as "coming on too strong for a woman" or being "not really a professional .. . just a housewife who went back to school." Her husband, who was a lawyer, identified this behavior as sex discrimination. Upon investigation, Sandler discovered that sex discrimination was illegal in some situations, but not at educational institutions in general. However, because the University of Maryland was a federal contractor, its sex discrimination could lead to the termination or nonrenewal of its federal grants. The pattern of discrimination against women in professorial positions was "industry-wide," so Sandler could and did file class-action complaints with the US Department of Labor against numerous universities, including the entire University of California system and the University of Wisconsin [18]. Sandler explained in 1997:

Because these were administrative charges filed with a federal agency rather than a lawsuit filed in court, it was not necessary for me to be an attorney. There were no special forms to fill out. Individuals did not need to be named; the charges were filed on behalf of all women in higher education.

In May 1971, the first AWM Newsletter communicated information about Sandler's complaints to mathematicians.

The basis of the complaints is not a law, but rather Executive Order 11246, amended by Executive Order 11375 (effective October 1968), forbidding discrimination by Federal contractors because of sex (as well as race, color, religion or national origin). There is no exclusion for educational institutions. Discrimination is not illegal-it can simply lead to cancellation of existing contracts or failure to make new grants. The contractors must not only not practice discrimination, but must have an affirmative action plan if necessary to remedy the effects of past discrimination.... HEW [the Department of Health, Education, and Welfare] has been designated as the compliance agency responsible for the enforcement of the executive order for all university contracts.

Among other things, HEW demanded that anti-nepotism rules be rescinded.

\section{1: Anti-nepotism Rules Crumble}

In 1971, the American Association of University Professors (AAUP) revived its committee on women (Committee W) which had been discontinued in 1928. An outcome of the 
committee's early actions was the official policy statement, "Faculty Appointments and Family Relationship,"

calling for the rescinding of laws and institutional regulations which subject faculty members to any automatic exclusion from academic employment solely on the grounds of being related to a member of the same family on the faculty of an institution.

This statement was endorsed by the AAUP in April 1971 and by the Association of American Colleges in June 1971.

Several major universities then quickly rectified the situations of wives who had held untenured positions for years [19]. For example, Mary Ellen Rudin and her husband, both mathematicians, although with different specialties, had come to the University of Wisconsin in 1959. This, her husband wrote,

turned out to be exactly the right kind of place for us - the right kind of city and the right kind of Mathematics Department. There is no point in describing in detail what we did for the next 33 years. I taught my classes, had graduate students, worked with colleagues, wrote papers and books, exactly what a professor is supposed to do. Ellen did the same, first as a part-time temporary lecturer, until she was suddenly promoted to a full professorship ... (the antinepotism rules, which were actually never a law, had fallen into disrepute).

Berkeley's anti-nepotism rule was rescinded in 1971, according to Margaret Rossiter, who cites evidence from Scott's files [19]. Susan Graham, a new hire in computer science, was about to marry Michael Harrison, who was already on the faculty. Her appointment was initially disapproved, but the decision was reversed a month later after the anti-nepotism rule was changed. However, this change had no effect on regularizing the situation of Emma Lehmer because, according to Calvin Moore, both Lehmers were "virtually at the age of mandatory retirement." But, this objection did not apply to Lehmer's younger colleague Julia Robinson.

As a graduate student, Julia Robinson worked with Elizabeth Scott in Neyman's statistics lab during World War II (an opportunity to gain research experience, although, unlike Lehmer, not in her chosen field). ${ }^{9}$ Like Emma Lehmer, she had a husband in the UCB mathematics department who was in her field (mathematical logic). Again like Lehmer, her husband's opportunities for interaction with other researchers seem to have helped her to become

\footnotetext{
${ }^{9}$ A remembrance from Scott in the November 1985 Notices describes the maneuver that allowed Robinson to be paid for her work in the statistics lab despite the anti-nepotism rule.
}

part of a mathematical research community. For example, Robinson's husband and her advisor Alfred Tarski attended weekly "logic lunches" in the Faculty Club's main dining room. Because the main dining room was restricted to men, Robinson could not attend. ${ }^{10}$ Instead, she learned from her husband about a question that became part of her thesis, and later about a conjecture that stimulated her approach to Hilbert's 10th problem, both posed by Tarski at lunch.

Robinson was younger than Lehmer-and had a PhD. Moreover, her husband had taken early retirement in 1971. Like Lehmer, she had worked as a temporary lecturer in mathematics, although between 1960 and 1975, not during World War II. How this was consistent with the UCB anti-nepotism rule is unclear. Perhaps the rule was waived in order to allow her to teach or run a seminar on the significant contributions that she made toward a solution of Hilbert's 10th problem during the 1960s. Or perhaps she was unpaid, as the "volunteer professor" Maria Goeppart Mayer was at the University of Chicago physics department during the 1950s [18].

If the Berkeley mathematics department immediately offered a full professorship to Julia Robinson in 1971 as Wisconsin did for Mary Ellen Rudin, this is a well-kept secret. Instead, something rather curious happened four years later.

\section{Hiring Regulations Change}

Before 1970, faculty hiring occurred via the "old-boy network." In 2016, Susan Ervin-Tripp, a psychologist hired by Berkeley in 1958 and member of Scott's CSAW, remarked in her oral history,

It's hard to believe but they didn't advertise jobs. There was no public advertising of positions in the old days before 1970. It was considered inappropriate to apply for a job. I can't remember how I came as a visitor, whether somebody wrote them to recommend me or what. You weren't supposed to apply for a job. It was sort of like an arranged marriage. For instance, one of the reasons that I knew about this was that Dan Slobin told me how he had been hired [in 1964]. The [UCB] chair of psychology called, I guess it was probably Roger Brown in the Harvard social relations department and said, "Have you got any good men?" This sounds funny. Dan got hired without giving a job talk and before he'd even chosen a thesis topic. Isn't that amazing? [laughter] So he was promised this job. He did a fast thesis basically so he could come. [laughter]

\footnotetext{
${ }^{10}$ In 1969, after an angry letter from Elizabeth Scott, faculty women were no longer excluded from the Faculty Club [7].
} 
In 1989, Saunders Mac Lane, a very prominent mathematician at the University of Chicago, described how new graduates were matched with jobs:

all the active [research] mathematicians ... had pretty shrewd ideas as to the level of mathematical activity at many schools, and they also had quite detailed (but perhaps mistaken) knowledge of the qualities of their own current products. So when they heard that Oberlin College, or the women's college of North Erehwon, or the University of $\mathrm{W}$ had a vacancy, they knew which of their graduates would be an appropriate candidate there, and they acted accordingly.

"Acting accordingly" sometimes involved calling the head of a department with a vacancy to recommend one's student. This could (and did) result in women not being recommended for jobs at top departments. (As Mac Lane put it, "Chicago did not normally send its women PhDs to universities anxious to acquire research hot-shots.")

Other types of employment constraints are illustrated by the experiences of Dorothy Bernstein, who graduated from Brown University in 1939 and became the first woman president of the MAA in 1979. When looking for her first job, she consulted a well-informed person at Brown:

$[\mathrm{H}] \mathrm{e}$ took out a map of the United States, covered the region west of the Mississippi and said, "You can't get a job there, because you are a woman." Then he covered the part south of the Ohio River and said, "And, you can't get a job there because you are Jewish." That left the Northeast quadrant. [6]

Expectations that women would not do research after their dissertations may have helped to reinforce the practice of not recommending them for positions at research-intensive departments_creating a vicious circle (see Table 1). According to Mac Lane:

In this period [1931-1960], women were encouraged to study for the PhD degree at Chicago, and there was a role model on the staff to help and support them (Mayme I. Logsdon ${ }^{11}$ ). But these women students were not really expected to do any substantial research after graduation; the doctorate was it, and in many cases the thesis topic was chosen to suit. ... I might add that for some of the men-students

\footnotetext{
${ }^{11}$ After being widowed in 1910, Logsdon studied at the University of Chicago. She earned her PhD at the age of 40 and was a Chicago faculty member until 1946. She did not remarry. She taught a required undergraduate survey course required of all undergraduates, served as a dean from 1923 to 1927, and was head of a graduate dormitory [10, 13]. Until 1982, she was the only woman at Chicago to hold a rank above instructor [10].
}

there was the same low level of research expectations-but not for all.

Like Logsdon, Mary Sunseri was a professor at a top department. She earned her masters degree from Stanford in mathematics in 1940; taught at San Jose State University for a year; and returned to Stanford as a faculty member, becoming an associate professor in 1969 and a professor in 1979. She taught only undergraduate calculus and mathematical analysis courses. She won awards for teaching and retired in 1986. Like Sperry and (especially) Levy, the duties of Logsdon and Sunseri reflect the association of women with education rather than research.

In the 1970s, affirmative action was intended to replace old-boy hiring practices with a system in which jobs were advertised and hiring was based on applications and interviews. Percentages of women hired or in the applicant pool were compared with percentages of qualified women (e.g., women with PhDs). In general, the transition to this new system was neither smooth nor immediate (see Rossiter's book on women scientists after 1972). Although its administration had an academic assistant for affirmative action and another for the status of women, Berkeley's transition was no exception. This is illustrated below for the case of the mathematics department.

\section{Women Lecturers and Graduate Students at UCB: 1968-1980}

Some well-known women who were lecturers in the UCB mathematics department between 1968 and 1980 were:

- Mary Gray (AWM president 1971-73, fellow of the AMS, fellow of the American Statistical Society)

- Lenore Blum (AWM president 1975-1978, fellow of the AMS)

- Jill Mesirov (AWM president 1989-1991, fellow of the AMS)

- Chuu-Lian Terng (AWM president 1995-1997, fellow of the AMS)

- Ruth Charney (AWM president 2013-2015, fellow of the AMS, AMS president 2021-2022)

- Karen Uhlenbeck (MacArthur fellow 1983, American Academy of Arts and Sciences fellow 1985, NAS 1986, fellow of the AMS, Abel Prize 2019)

- Michèle Vergne (American Academy of Arts and Sciences fellow 1998, fellow of the AMS). ${ }^{12}$

Although Berkeley's anti-nepotism rule was rescinded in 1971 and affirmative action was required because the CSAW report had documented patterns of discrimination in the mathematics department, none of these former lecturers ever became members of the UCB tenure-track faculty [3]. According to Calvin Moore, in 1971 an assistant professor position was offered to Uhlenbeck, who declined, and

\footnotetext{
${ }^{12}$ This list of honors is not exhaustive.
} 
to Michèle Vergne in 1972. Vergne accepted, but was not immediately able to take up duties, then resigned [14].

Some reasons for Berkeley's lack of success in hiring women are given in an April 1974 letter from faculty member Morris Hirsch to his colleagues:

There are two different causes for this state of affairs. One is that too few of us want any Affirmative Action; many, in fact, consider it bad policy ("You mean we should hire inferior mathematicians?").

A second cause is the Dean's insistence that we recruit only within narrowly specified fields. This virtually rules out the possibility of hiring women or minority mathematicians since there are relatively very few of them.

Another reason might have been the atmosphere for women, which was "incredibly horrible-for the women instructors as well as the students" [11]. Many students (both male and female) did not pass their qualifying exams or complete their degrees. Competition among graduate students may have been intensified by the unusually high ratio of graduate students to tenure-track faculty [14]. Among other things (such as sexist comments), one incident harked back to Annie Biddle's termination in 1933. A married female graduate student became pregnant and her teaching stipend was reduced because she didn't "need as much money" [11]. Recall that Biddle's file said she would not be destitute because she had married a practicing attorney.

In 2020, Chuu-Lian Terng commented, "During the time I was an instructor at UC Berkeley, the atmosphere for women was far from ideal." She added, "So it was very fortunate that I was part of the friendly and supportive differential geometry group led by S. S. Chern." This remark suggests the effect that individuals and subfields may have, resulting in quite different experiences within the same department or within mathematics.

Another effect on women's experiences may be their academic positions. As evidenced by the list above, the department had no problem hiring women as lecturersoffers were made and some women accepted. However, tenure-track positions (which were higher status and longer term) were another matter. In 1970, a memo from the UCB chancellor's office reminded deans and department chairs that sex discrimination in employment was illegal. In response, mathematics department chair John Addison asserted "we think we have gone out of our way to make sure women are not discriminated against," noting that three women (Lenore Blum, Julia Robinson, Karen Uhlenbeck) had been hired as lecturers and the full-time non-academic staff of 20 was entirely female. ${ }^{13}$ In response to the vice chancellor's question, "Do women get appointed only as lecturers-not as regular ladder [tenure-track] members?," he said the department was "hopeful" that the women appointed as lecturers would be promoted to assistant professors [7]. They weren't.

\section{5: A New Hire at Berkeley}

In 1975, Marina Ratner was hired as an assistant professor, one of the tenure-track faculty. ${ }^{14}$ According to one account, the mathematics department established a "Committee W" which was charged with searching for and recommending women and minority candidates. Faculty member Rufus Bowen, who was aware of Ratner's work, brought it to the committee's attention. Her work, which was in ergodic theory, was viewed with favor, and her training in Moscow during the Cold War complemented rather than replicated the training of the existing UCB ergodic theorists [14]. At the time, this situation was described somewhat differently by faculty member Robion Kirby in a letter to the student newspaper The Daily Californian:

Apparently she is the best woman candidate, for a special committee searched hard. In research she is well qualified, and a few years ago we would have been lucky to get her. Now competition is sharper. There is at least one man (I think several) whose research looks significantly better (many of those voting for [Ratner] agree with this).

In response, faculty member David Goldschmidt's letter to the Daily Cal noted that:

the two individuals in question are in completely separate mathematical specialties and that there is no one in our department who is even able to read both sets of papers, much less to give a competent technical evaluation of the work. In fact, there may well be no such individual anywhere in the world. . . . among those of our colleagues who are competent to comment technically on the work of [Ratner], opinion was unanimous that there were no better qualified people available in her field. This evaluation was supported by outside letters.

Hiring Ratner involved an unusual extra step. Faculty member Stephen Smale described it in a letter written to

\footnotetext{
${ }^{13}$ The first staff member, Sarah Hallum, had been hired in 1936 as a parttime secretary and stenographer while a graduate student in mathematics. She eventually became a full-time staff member, obtained a masters degree in mathematics, and retired in 1975 [14].

${ }^{14}$ It may be worth noting that Ratner was the first woman assistant professor at the UCB mathematics department who had a child.
} 
department chair Maxwell Rosenlicht and published in the AWM Newsletter:

On Feb. 27, the department voted 26 to 7 to offer regular appointments to Drs. Marina Ratner and Robert [sic] Stanley. The normal procedure would be for you [the chair] to process these appointments. In fact, your letter I mentioned imposes a completely new obstacle to the appointment of Ratner without precedent in the department history. In the name of affirmative action procedures (what irony) you poll the department with the following question: " 1 believe that Ratner is superior to, or at least as well qualified as, the other leading candidates for the pure mathematics position." with boxes marked yes and no and space for reasons. The Stanley appointment is not mentioned in your letter.

The latter two letters suggest that for some faculty members the question was not whether Ratner was the best-qualified candidate available in her field but whether she was the best candidate available in some broader category. As another faculty member put it: "The problem is that, while there are many competent women mathematicians, there are very few outstanding ones and no 'super stars."'

This sort of slippage was not unique. Two examples from earlier eras illustrate how criteria for hiring women could shift from "qualified for the position" to "best qualified in some broader arena." The first comes from 1936. Hertha Sponer (a German refugee then reputed to be the third best woman physicist in the world) had been hired as a full professor at Duke University. The president of Duke received a letter from a Caltech physicist who was concerned about Sponer and "the policy of bringing women into a university department of physics." His rationale: Finding a female physicist as accomplished as Lise Meitner or Marie Curie was unlikely; and young men were "drawn into the graduate department by the character of the men on its staff, rather than the character of its women" [17].

The second example begins in the 1950s. Although the mathematicians in Caltech's small department were anxious to hire Olga Taussky Todd, the Caltech trustees apparently required assurances that she was "considered the leading living woman mathematician in the world." This assurance was repeated in 1963 when Taussky Todd was granted tenure-not as a professor, but as a research associate. ${ }^{15}$ In 1971, Taussky Todd's public display of acceptance stopped after she encountered press coverage about a young assistant professor of English who was the

\footnotetext{
${ }^{15}$ Although Caltech had "no fixed or stated policy" on nepotism, her husband had been hired as a tenured professor when she was hired as a research associate in 1957 [8].
}

first woman on Caltech's faculty. "She went straight to the administration and had her rank changed to professor" [6].

\section{6: A Sometime Lecturer Becomes a Full Professor}

In 1975, Saunders Mac Lane, a distinguished professor at the University of Chicago and past president of the American Mathematical Society, successfully nominated Julia Robinson for membership in the National Academy of Sciences [6]. Department chair John Kelley then "seize[d] this opportunity," as Calvin Moore puts it, to make her a professor.

But, since the advent of affirmative action, the department (and the University of California system) had been under pressure to hire more women for several years (see, e.g., [7]). Why wasn't Robinson already a professor? Responses varied. Years later, some members of the department described the chair's action as "seizing the opportunity to challenge the university's nepotism rule." However, this rule had been rescinded in 1971. Moreover, Robinson's husband had retired by $1973 .{ }^{16}$ In 1968 , responses to this question were "vague reasons alluding to [Robinson's] health, nepotism rules, and some linearly ordered list of logicians" [4]. In 1970, the department chair (a logician) said that were it not for the nepotism rules, the department "might well have appointed her to a regular faculty position long ago" (Addison as quoted in [7]).

The inconsistency in these responses suggests that some department members did not favor having Robinson join the tenure-track faculty-or perhaps couldn't imagine it. Depending on the questioner, it seemed that any answer would do as long as it justified not appointing her. Apparently, some faculty members did not see her as outstanding or a superstar. This suggests why the department chair might have decided that a useful precursor to a tenured appointment would be an NAS membership. And this was not just any NAS membership-Robinson was the first woman to be elected in mathematics.

In any case, appointing Robinson as a professor after her election seems to have avoided the awkwardness that occurred after Ratner's hire. Perhaps her NAS membership reassured UCB mathematicians outside Robinson's field, just as statements that Taussky Todd was the best living woman mathematician seem to have reassured the Caltech trustees.

Robinson was not the only woman to be offered a professorship after being elected to the NAS. In 1956, Maria Goeppart Mayer, "volunteer professor" at the University of Chicago, was elected to the NAS; three years later, she and her husband accepted professorships at UC San Diego in physics and chemistry, respectively. In 1963, she became the second woman to receive the Nobel prize in physics.

\footnotetext{
${ }^{16}$ One source says he retired in 1971, another says 1973
} 
Unfortunately, this variant of what the historian Margaret Rossiter calls the "Madame Curie strategy" — hiring women with exceptional qualifications ${ }^{17}$ that are recognizable by outsiders and nonspecialists-is often impractical. It is also unfair, unless the same standard is applied to all.

\section{Concluding Remarks}

The small sample in this article illustrates a variety of changes in the lives of women in the mathematical sciences at Berkeley. As the decades passed and Berkeley's prestige grew, its emphasis on research increased and connection with K-12 education dwindled. Its statistics and logic programs took root; statisticians Elizabeth Scott and Evelyn Fix became tenured faculty members, first in the mathematics department, then in the statistics department.

As evidenced in this narrative, employment barriers were not uniform for all women in all mathematics departments in all capacities. Before 1971, Mayme Logsdon at the University of Chicago and Mary Sunseri at Stanford achieved professorial rank in roles that deemphasized research, as did Sophia Levy at Berkeley. Before and after 1971, many women were hired as lecturers, secretaries, and technical typists. In a few cases, barriers to advancement seem to have been procedural: researchers Mary Ellen Rudin and Olga Taussky Todd quickly became full professors in 1971.

Summarizing the employment situation for women in science in the 1920s and 1930s, Rossiter said:

although most of the barriers to women's advancement that one finds documented are administrative or procedural, at root they were cognitive and perceptual. [18]

As evidenced by responses to affirmative action in the 1970s at Berkeley and elsewhere [19], federal and university regulations may not immediately change the number of women on the faculty, nor faculty hearts and minds. University anti-nepotism rules were an important factor in dampening women's participation. But, their removal did not erase perceptions built on decades of experience.

This narrative illustrates two perceptions of women in mathematics. The rare woman who was labeled as outstanding in some broad category, e.g., "best woman mathematician," might obtain a professorship at a top school such as Berkeley or Caltech. If not, she might be hired for teaching, either as a lecturer or in a tenure-track position with no research expectations. The continued paucity of women in elite departments (see tables in [2]) suggests that these limited perceptions of women in mathematics have been slow to change.

\footnotetext{
${ }^{17}$ Recall that Curie is the only person to have received Nobel prizes in two scientific fields.
}

\begin{tabular}{|c|c|c|c|}
\hline & $\begin{array}{l}\text { PhD } \\
\text { Year }\end{array}$ & Name & Adviser \\
\hline 1 & 1911 & $\begin{array}{l}\text { Annie Dale Biddle Andrews } \\
(1885-1940)\end{array}$ & D. N. Lehmer \\
\hline 2 & 1918 & $\begin{array}{l}\text { Mary Helen Sznyter Sagal } \\
(1893-1975)\end{array}$ & J. H. McDonald \\
\hline 3 & 1920 & $\begin{array}{l}\text { Elsie Mcfarland Buck } \\
(1897-1984)\end{array}$ & J. H. McDonald \\
\hline 4 & 1921 & $\begin{array}{l}\text { Nina M. Alderton Moore } \\
(1890-1973)\end{array}$ & D. N. Lehmer \\
\hline 5 & 1932 & $\begin{array}{l}\text { Emma Whiton McDonald } \\
(1886-1948)\end{array}$ & D. N. Lehmer \\
\hline 6 & 1933 & $\begin{array}{l}\text { Dorothy Brady } \\
(1903-1977)\end{array}$ & J. H. McDonald \\
\hline 7 & 1935 & $\begin{array}{l}\text { Andrewa Noble } \\
(1908-1993)\end{array}$ & D. N. Lehmer \\
\hline 8 & 1940 & $\begin{array}{l}\text { Virginia Wood Wakerling } \\
(1915-1997)\end{array}$ & J. H. McDonald \\
\hline 9 & 1941 & $\begin{array}{l}\text { Elizabeth Sherman Arnold } \\
(1915-1992)\end{array}$ & J. H. McDonald \\
\hline 10 & 1948 & $\begin{array}{l}\text { Evelyn Agnes Fix } \\
(1904-1965)\end{array}$ & Jerzy Neyman* \\
\hline 11 & 1948 & $\begin{array}{l}\text { Louise Hoy Chin Lim } \\
(1922-1985)\end{array}$ & Alfred Tarski \\
\hline 12 & 1948 & $\begin{array}{l}\text { Julia Bowman Robinson } \\
(1919-1985)\end{array}$ & Alfred Tarski \\
\hline 13 & 1949 & $\begin{array}{l}\text { Esther Seiden } \\
(1908-2014)\end{array}$ & Jerzy Neyman \\
\hline 14 & 1950 & $\begin{array}{l}\text { Wanda Montak Szmielew } \\
(1918-1976)\end{array}$ & Alfred Tarski \\
\hline 15 & 1953 & $\begin{array}{l}\text { Anne Davis Morel } \\
(1920-1984)\end{array}$ & Alfred Tarski \\
\hline 16 & 1957 & $\begin{array}{l}\text { Mary I. Hanania Regier } \\
(1926-2020)\end{array}$ & Elizabeth Scott* \\
\hline 17 & 1959 & $\begin{array}{l}\text { Kathleen Baxter O'Keefe } \\
(1923-2012)\end{array}$ & $\begin{array}{l}\text { Abraham } \\
\text { Seidenberg }\end{array}$ \\
\hline
\end{tabular}

*In 1955, Neyman and Scott became members of the newly formed statistics department.

Sources: Pre-1940: [10]; 1940s and 1950s: https://women becomingmathematicians.net/db/

Appendix. Women granted PhDs by the Berkeley mathematics department before 1960 .

ACKNOWLEDGMENTS. Thanks to Charity Hirsch, Morris Hirsch, Margaret Murray, Anne MacLachlan, Laura Turner, and two anonymous reviewers for comments on earlier versions of this article.

The author was a graduate student at Berkeley from 1975 to 1978. 


\section{HISTORY}

\section{References}

[1] AWM Newsletter Archive. https://www.drivehq.com /folder/p8755087.aspx

[2] G. Benkart, K. Lauter, and S. Wiegand, AWM at 50 and beyond, Notices Amer. Math. Soc. 68 (2021), no. 3, 387397. https://www.ams.org/journals/notices/202103 /rnoti-p387.pdf

[3] L. Blum, A brief history of the Association for Women in Mathematics: The presidents' perspectives, Notices Amer. Math. Soc. 38 (1991), no. 7, 738-754. https://www.ams.org /journa1s/notices/199109/199109Fu71Issue.pdf

[4] L. Blum, Review of Julia: A life in mathematics, American Mathematical Monthly 105 (1998), no. 10, 964-972.

[5] J. Brillhart, Emma Lehmer 1906-2007, Notices Amer. Math. Soc. 54 (2007), no. 11, 1500-1501. https://www.ams . org/notices/200711/tx071101500p.pdf

[6 B. Case and A. Leggett (eds.), Complexities: Women in Mathematics, Princeton University Press, Princeton, NJ, 2005. MR2118372

[7] A. Golbeck, Equivalence: Elizabeth L. Scott at Berkeley, CRC Press, Taylor \& Francis Group, Boca Raton, FL, 2017.

[8] J. Goodstein, Olga Taussky Todd, Notices Amer. Math. Soc. 67 (2020), no. 3, 345-353. https://www.ams.org /journals/notices/202003/rnoti-p345.pdf https:// dx.doi.org/10.1090/noti2038

[9] J. Green and J. LaDuke, Pioneering Women in American Mathematics: The Pre-1940 PhD's, American Mathematical Society and London Mathematical Society, Providence and London, 2009.

[10] J. Green and J. LaDuke, Supplementarymaterial for Pioneering Women in American Mathematics: The Pre-1940 PhD's, 2016. https://www.ams.org/pub1ications/authors/books /postpub/hmath-34-PioneeringWomen.pdf

[11] C. Henrion, Women in mathematics: The addition of difference, Indiana University Press, Bloomington and Indianapolis, 1997.

[12] Emma Lehmer, On the advantages of not having a PhD, in: The Lehmers at Berkeley, online exhibit, n. d. https:// bancroft. berkeley.edu/Exhibits/Math/dh1a.htm1

[13] S. Mac Lane, Mathematics at the University of Chicago: A brief history, in: A century of mathematics in America, part II, P. Duren, R. A. Askey, and U. C. Merzbach (eds.), History of Mathematics, vol. 2, American Mathematical Society, Providence, RI, 1989. Republished in 2012. https:// celebratio.org/MacLane_S/article/459/

[14] C. Moore, Mathematics at Berkeley: A history, A K Peters, Wellesley, MA, 2007.

[15] M. Murray, Women becoming mathematicians: Creating a professional identity in post-World War II America, MIT Press, Cambridge, MA, 2000.

[16] M. Murray, A celebration of women in mathematics at MIT, Notices Amer. Math. Soc. 56 (2009), no. 1, 42-47. https://www.ams.org/notices/200901/tx090100042p . $\mathrm{pdf}$

[17] M. Rossiter, Women scientists in America: Struggles and strategies to 1940, Johns Hopkins University Press, Baltimore, 1989. Original work published 1982.

[18] M. Rossiter, Women scientists in America: Before affirmative action, Johns Hopkins University Press, Baltimore, 1995.

[19] M. Rossiter, Women scientists in America: Forging a new world since 1972, Johns Hopkins University Press, Baltimore, 2012.
[20] Report of the Subcommittee on the Status of Academic Women on the Berkeley Campus, ERIC ID: ED042413, 1970. https://eric.ed.gov/?id=ED042413

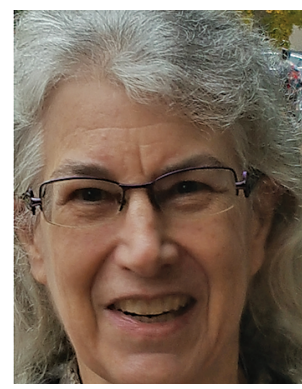

Cathy Kessel

Credits

Author photo is courtesy of Anne MacLachlan.

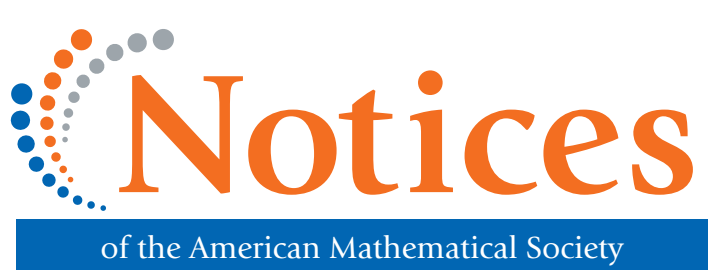

Connect with an audience of approximately 30,000 subscribers through Classified and Display Advertising in the Notices of the American Mathematical Society, available in print and online.

As the world's most widely read magazine aimed at professional mathematicians, the Notices is an excellent medium for announcing publications, products, and services, and for recruiting mathematical scientists in academia, industry, and government.

Learn more about advertising in the Notices at www.ams.org/noticesadvertising.

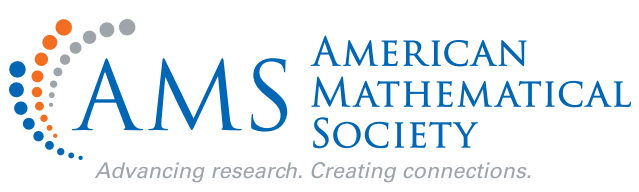

